\title{
TAPAUS MODULAATIO - huomioita Eurovision laulukilpailun musiikillis-visuaalisesta menestysreseptistä
}

Vuoden 2016 Eurovision laulukilpailussa ruotsalaiset juontajat Petra Mede ja Måns Zelmerlöw yltyivät tarkastelemaan kilpailun historiaa ja luonnetta kahdessa vauhdikkaassa show-numerossa. Siinä missä revyymäinen avausnumero juhlisti kilpailun ainutlaatuisuutta ja moninaisuutta, väliaikaesityksessä "paljastettiin" seitsenkohtainen resepti täydellisen viisuesityksen luomiseksi. Mukaansatempaavan sävelmän ja ikimuistoisen esiintymisasun lisäksi menestykseen tarvitaan juontajien mielestä muun muassa yläosattomia lihaksikkaita miesrumpaleita, partasuinen ikäihminen soittamaan tuntematonta perinneinstrumenttia ja vinyylilevyjä skrätsäilevä DJ.

Spektaakkelimaisesti toteutetun parodiahupailun kruunasi juontajien oma lauluesitys "Love Love Peace Peace", jonka aikana lavalle vyörytettiin yliampuvaa rekvisiittaa valeliekeissä roihuavasta pianosta jättimäiseen hamsteripyörään. Kappaleen sanoituksissa annettiin lisäohjeita lauluntekijöille ja vakuutettiin, että näillä keinoilla "olette parhaita ja voitatte Eurovision laulukilpailun!"

\section{Euroviisun alkemiaa}

Moni on aivan tosissaan yrittänyt päästä perille euroviisualkemiasta. Asiaa ovat vuosittain pohtineet lukemattomat säveltäjät, sanoittajat ja visualistit, jotka ovat toiveikkaasti laatineet ehdotuksensa kilpailua varten. Heidän lisäkseen täydellisen viisun metsästys on kiinnostanut toimittajia, viisufaneja, katsojia, data-analyytikkoja (esim. Aljanaki 2019) ja tutkijoita (esim. Scott 2010; Raykoff 2020).

Menestykseen tottuneessa Ruotsissa kaavaa on voitu tutkailla rennolla asenteella, siinä missä esimerkiksi Suomessa etsintään liittyi vuoteen 2006 ja Lordin voittoon asti kitkerä ja jopa kaoottinen sävy, kun kisakappaleen valitsemiseksi kokeiltiin mitä moninaisimpia karsintamenetelmiä. Menestymättömyys kasvoi kansallisen draaman ellei peräti tragedian mittoihin (ks. Pajala 2006, 318-347). Lordin voitonhuuman laannuttua ja epäonnistumisten palattua Suomen viisuarkeen edustuskappaletta on taas haettu vaihtelevin menetelmin. Ruotsissa puolestaan on jo kahden vuosikymmenen ajan käytetty pienin muutoksin samaa formaattia, joka sisältää eri kaupungeissa käydyt semifinaalit ja Tukholmassa järjestettävän finaalin.

On tietenkin selvää, että mitään universaalia voittolauluformulaa ei ole olemassa. 2020-luvun Eurovisio-esitykset ovat kappaleen aikarajoitusta ja laulajan pääroolia lukuun ottamatta hyvin erilaisia kuin 1950-luvun lopun esitykset. Erojen syyt ovat moninaiset alkaen teknologian kehityksestä ja päätyen kilpailun alati uusiutuneisiin 
sääntöihin. Usein muutokset ovat kytkeytyneet musiikkimuoteihin, joiden kehityskaaret ja periodit voivat olla pitkäkestoisia ja hitaasti hahmottuvia. Esimerkiksi vielä 1980-luvulla Eurovision laulukilpailussa duurisävellaji takasi useimmiten tien menestykseen. Vuosina 2000-2019 duurisävellyksellä yllettiin laskelmieni mukaan voittajaksi enää vain kuusi kertaa, ja tuoreimmissa duurimenestyksissäkin eli Portugalin Salvador Sobralin (2017) ja Alankomaiden Duncan Laurencen (2019) lauluissa kallistutaan vahvasti melankoliseen suuntaan (Laurencen "polymodaalinen" voittoviisu "Arcade" voidaan tosin tulkita yhtä lailla molli- kuin duurikappaleeksi, ks. Raykoff 2020, 65).

Omat pienet kaavavinoumansa löytyvät myös ruotsalaisjuontajien esityksestä. Se ei sinänsä ole yllättävää, sillä parodioissa näkemykset ovat historiaorientoituneita, ne saavat voimansa käytänteiden ja mielikuvien liioittelusta. Parodian tekijät ja esittäjät käyttävät hyväkseen piirteitä, jotka mielletään toisteisiksi ja suosituiksi, vaikka niiden kulta-aika on jo saattanut jäädä taakse tai ne eivät ehkä edes koskaan ole olleet ratkaisevassa roolissa.

Meden ja Zelmerlöwin esityksessä "voittaja" on miehen ja naisen muodostama lauluduo, joka kuuluttaa rauhaa ja rakkautta ja käyttää kertosäkeessä hyväksi tutun kuuloista musiikillista ratkaisua, sointujen kvinttikiertoa. Tosiasiassa mies-naispari on voittanut viisut vain kahdesti, vuosina 1963 ja 2011, ja vaikka sointujen eteneminen kvinttihyppäyksin alaspäin on ollut populaarimusiikin historiassa hyväksi havaittu menetelmä (esim. Gloria Gaynorin "I Will Survive", Pet Shop Boysin "It's a Sin" ja lukuisat jazzstandardit kuten "Fly Me to the Moon") ja enemmän tai vähemmän jokavuotinen vieras myös viisufinaalissa, ei sillä ole juurikaan saavutettu ykkössijoja Eurovision laulukilpailussa. Viimeisin selkeästi kvinttikiertoon nojautunut voittaja löytyy niinkin kaukaa kuin vuodelta 1975, jolloin parhaaksi viisuksi äänestettiin alankomaalaisen Teach-In-yhtyeen "Ding-a-Dong". Mitä voittajakappaleiden sanoituksiin tulee, niin rauhanlauluilla oli menestyksen hetkensä 1980-luvun vaihteessa (mm. Länsi-Saksan Nicolen voitto 1982 kappaleella "Ein bißchen Frieden"), mutta muuten tästä teemasta ei ole ollut voiton takeeksi.

Juontajien metaesityksen luonteeseen kuului, että tarjolla oli paljon puhetta musiikista. Esimerkkejä havainnollistettiin visuaalisin keinoin. Täydellisessä viisukappaleessa rumpu, perinneinstrumentti ja vinyylilevy pääsevät esille vain, jos niitä soittavat merkitykselliset henkilöt. Pianokaan ei ole mitään, ellei se roihua liekeissä. Kvinttikiertoa ei sen sijaan mainittu, asian visualisoiminen olisikin epäilemättä tuottanut haasteita ja suurimmalle osalle katsojia tällainen sävellysformaatin erityispiirre olisi joka tapauksessa näyttäytynyt turhan teoreettisena. Mielenkiintoisempaa sen sijaan on se, että vaikka laulun aiheet mainittiin (rauha ja rakkaus) ja kappaleen rakennettakin korostettiin (alku, kertosäkeistö, loppuhuipennus), niin itse laulamisesta ja sen keskeisestä roolista voiton tuottajana ei sanottu mitään. Eurovision laulukilpailun esittämistä koskevat säännöt ovat vuosikymmenien aikana muuttuneet moneen otteeseen, mutta yksi on pysynyt: mukana täytyy olla laulua ja se tulee esittää elävänä "tässä ja nyt". Eurovision laulukilpailussa ihmisen tuottama ääni on koettu takeena esityksen autenttisuudesta, eikä siitä ole juurikaan tingitty. Vuoden 2021 finaaliin kyllä päätettiin koeluonteisesti hyväksyä se, että taustalaulut voidaan muiden musiikillisten äänien tavoin toistaa etukäteen äänitettynä, mutta pääsolistin tulee edelleen esittää osuutensa elävänä, livenä.

Lauluääntä on hyvin vaikea visualisoida, kyseessähän on "instrumentti, jota ei voi nähdä", joten on ymmärrettävää, jos se ei mahtunut Meden ja Zelmerlöwin viisureseptiin. Täysin vailla auditiivisten ratkaisujen huomioimista ruotsalaisjuontajien esitys ei kuitenkaan ollut. Mukana oli yksi musiikillinen keino, jonka juontajapari mainitsi ja siirtyi sitten itse esittämään sen. Kyseessä oli "change the key", sävellajin vaihdos. 


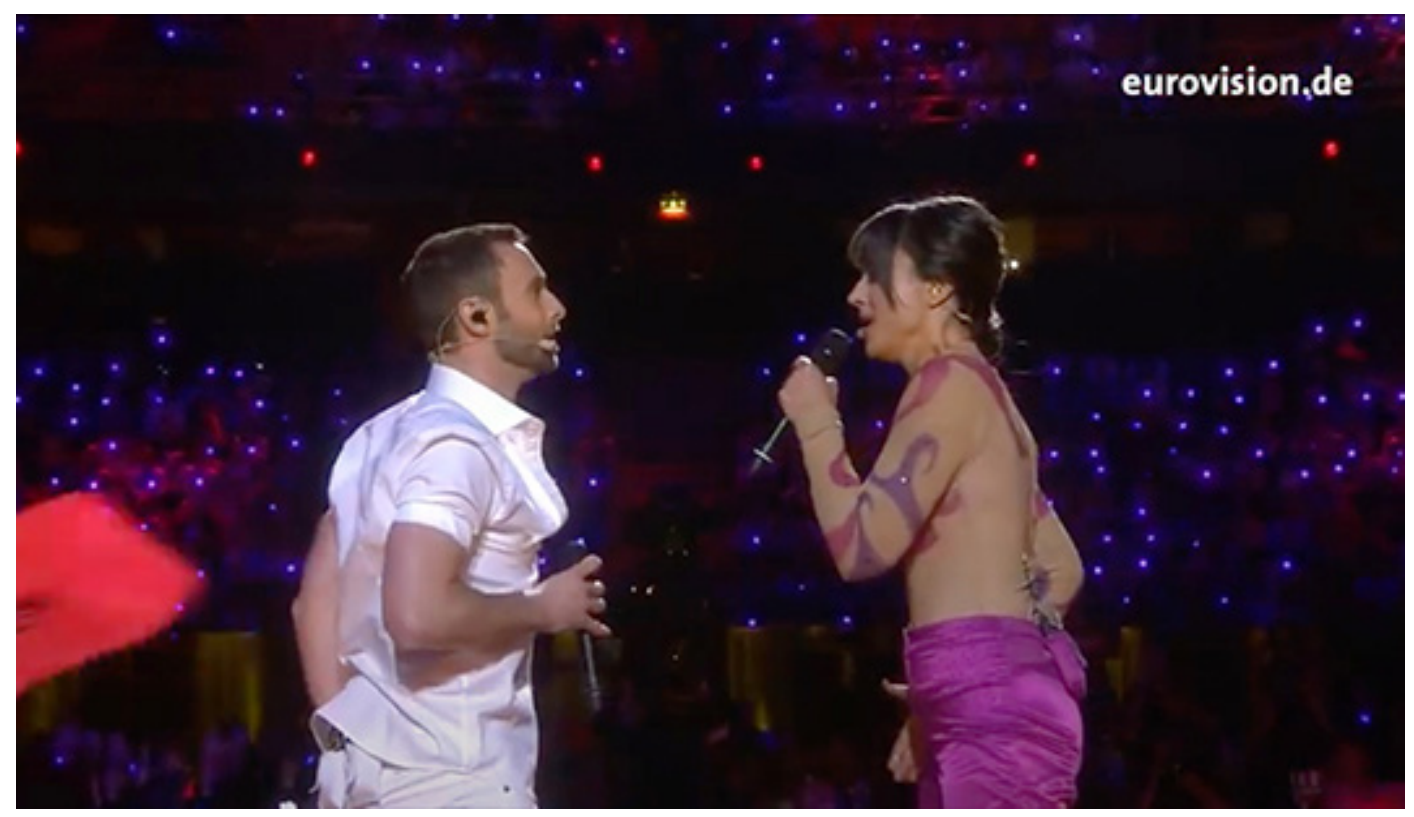

Juontajat Måns Zelmerlöw ja Petra Mede siirtyvät "täydellisessä viisukappaleessa" puoli sävelaskelta ylemmäksi ja kuuluttavat sen seuraukset: "It's you and me and when we change the key we'll give the world the show." Kuva: Eurovision.tv/YouTube.

Sävellajin vaihdos kesken kappaleen eli musiikinteorian termein ilmaistuna modulaatio on keino, joka on Eurovision laulukilpailun historiassa kuulunut oleellisesti viisusäveltäjien tehokeinoihin. Onko se ollut voiton tae? Entä miten siirtymä on esityksellisesti ja visuaalisesti huomioitu kilpailulavalla ja televisioinnissa?

\section{Vissin ja Carolan modulaatiot}

Euroviisufanit ovat tilastoineet, listanneet ja äänestyttäneet internetsivuillaan koko joukon laulukilpailuun liittyviä ilmiöitä parhaista voittajakappaleista surkeimpiin esiintymisasuihin. Myös sävellajin vaihdokset ovat saaneet sijansa. Kreikan edustuslaulaja Anna Vissi ei kotikisoissa 2006 yltänyt kärkisijoille suureellisella heavypopballadillaan "Everything", mutta modulaatiolistauksissa hän on pärjännyt hyvin (esim. DS Fantasy 2021; Jameson 2013). Kappaletta voidaankin pitää Eurovision laulukilpailun historiassa modulaatiokonvention tyylipuhtaana edustajana.

Vissin kappaleessa sävellajin vaihdos tapahtuu yhden kerran, viimeisen neljänneksen alkaessa, jolloin Vissi laulaa väkevällä äänellään "I'm still in love" ja jää venyttämään viimeistä tavua "looove". Laulaja sulkee silmänsä ja kääntää kasvonsa kohti kattoa, nostaa mikrofonin päänsä yläpuolelle, ojentaa toisen käden sivulleen. Taustasäestys on hiljentynyt. Pitkä tavu jatkuu ja liukuu puoli sävelaskelta ylöspäin samalla, kun Vissi heittäytyy polvilleen. Pyroliekit leimahtavat. Rumpujen ja sähkökitaran särösointujen leimaama säestys rävähtää liikkeelle.

Vissin esityksessä kamera on juuri ennen kliimaksia ja koko sen keston nauliutunut laulajaan, itse asiassa peräti viidentoista sekunnin ajan, mikä on pieni ikuisuus nopeiden kuvaleikkauksien leimaamassa televisio-ohjelmassa. Kappaleen loppuosan rymistyksessä kuvakulmat jo vaihtelevat, mutta Vissi itse laulaa viimeiset osuutensa polvillaan ylävartalo vimmaisesti heiluen. Tuulikone hulmuttaa hänen vaaleita hiuksiaan ja esiintymisasuaan. 


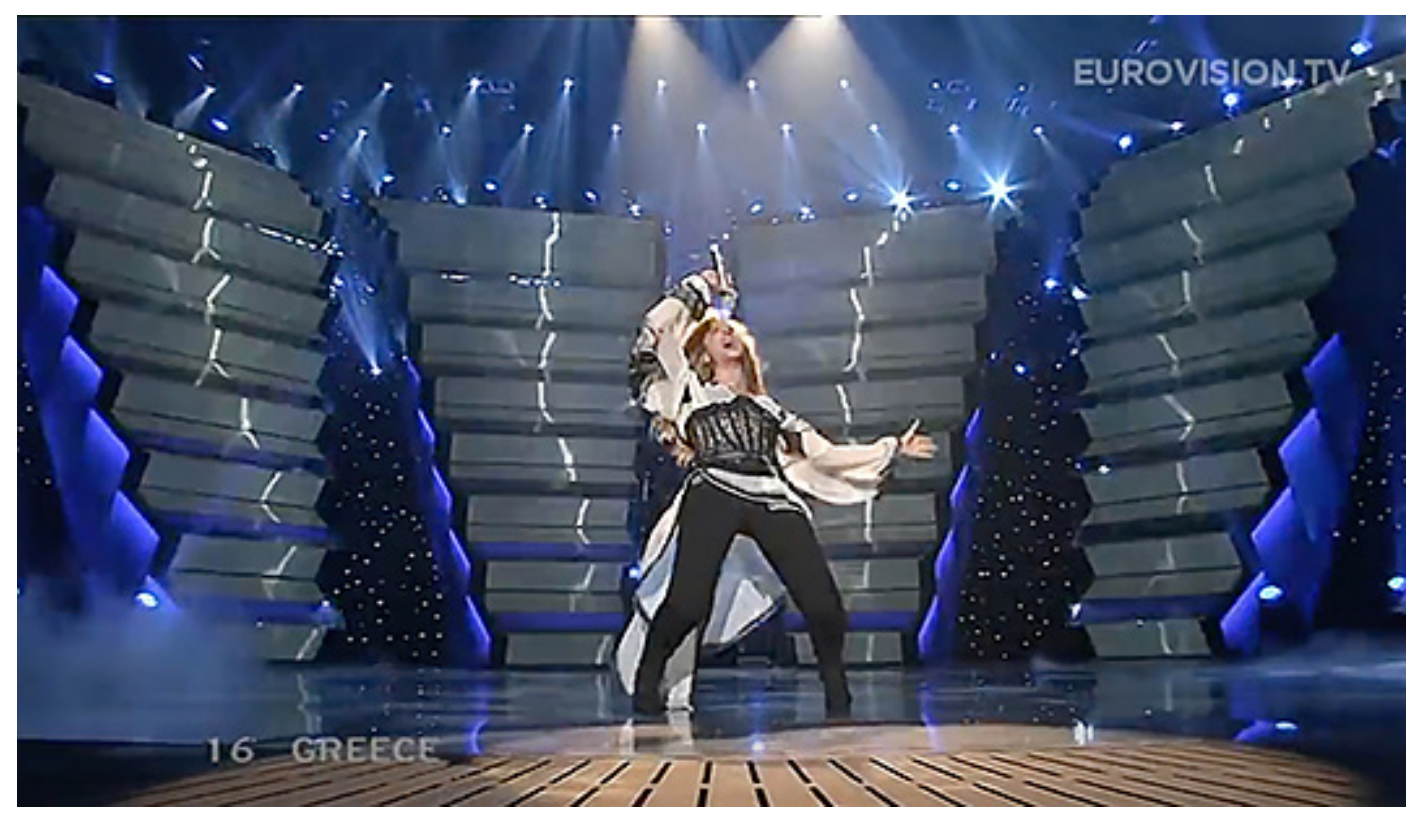

Kreikan Anna Vissi vajoaa alas ja liu'uttaa samalla lauluääntään puoli sävelaskelta ylös edustuskappaleessaan "Everything" vuonna 2006. Ollaan kolmiminuuttisen laulun kohdassa 02:20. Kuva: Eurovision.tv/YouTube.

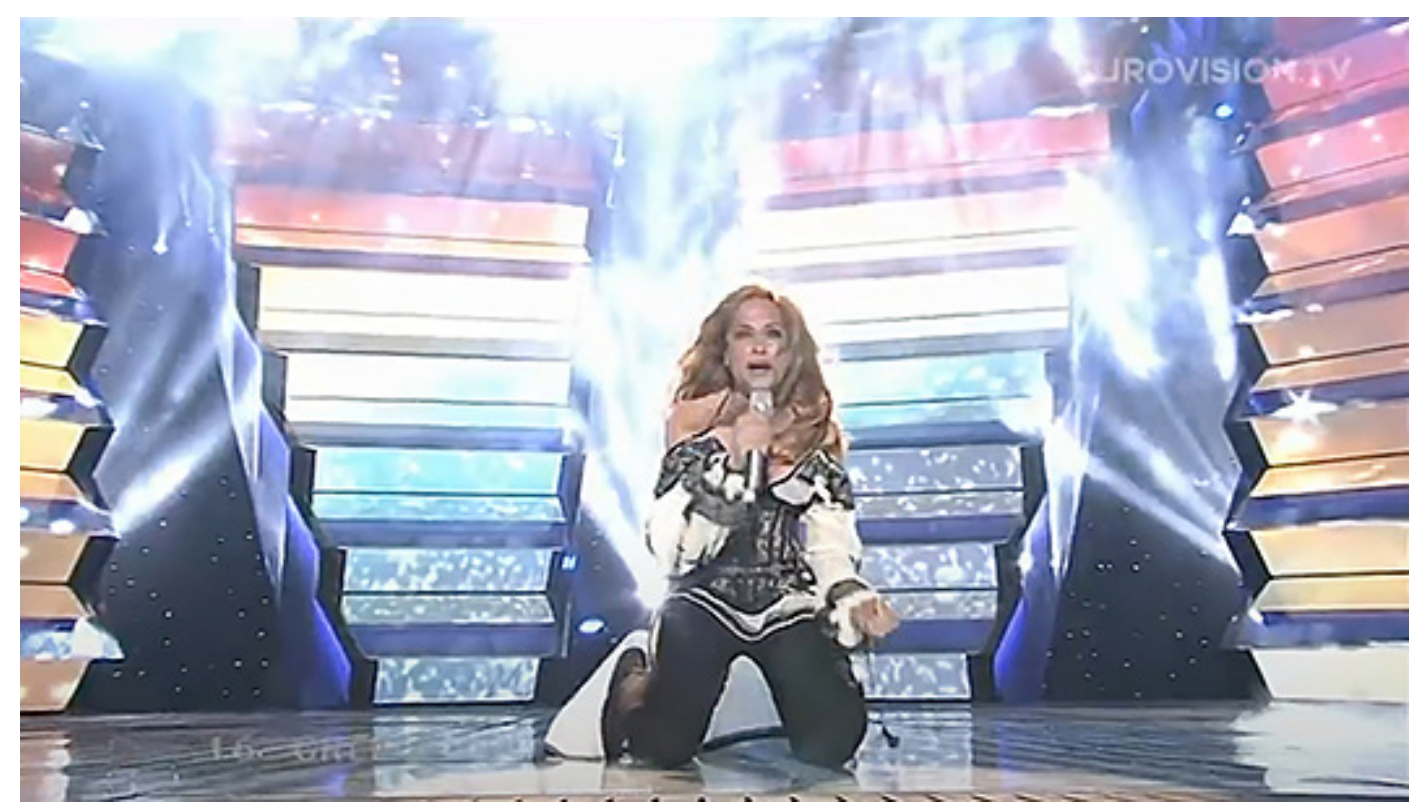

Kohta 02:26. Anna Vissi on juuri ottanut modulaation haltuun. Kuva: Eurovision.tv/YouTube.

Musiikinteoriaa tuntematon kuuntelijakin yleensä äkkää modulaation. Sävellys tuntuu jotenkin muuttuvan, tunnelma kohoaa. Populaarimusiikin sanastossa kappaleen loppupuolella tapahtuvasta nostatuksesta, jossa "pannaan uusi vaihde päälle", on käytetty rekkakuskin toimintaa kuvaavaa nimitystä "truck driver's gear change". Musiikinteoriassa modulaatiolla ei kuitenkaan ole yksiselitteistä määritelmää. Modulaatiolla kyllä tarkoitetaan sävellajin vaihdosta (termiä on tosin käytetty myös kuvaamaan signaalinmuutosta elektronisessa musiikissa), mutta vaihdostyyppejä voi olla useita erilaisia riippuen sävellajin kestosta ja vakiintuneisuudesta. Tässä yhteydessä ei ole tarpeen lähteä erittelemään vaikkapa diatonista, kromaattista ja 
enharmonista modulaatiota; riittää, kun todetaan, että Eurovision laulukilpailun historiassa modulaatiota on käytetty varsin monipuolisesti. Klassisessa viisumodulaatiossa sävellaji vaihtuu äkillisesti puoli sävelaskelta ylöspäin, esimerkiksi Vissin kappalessa F-duurista Fis-duuriin, eikä sen jälkeen enää palata alkuperäiseen sävellajiin, mutta monissa muissa viisukappaleissa siirtymät ovat olleet väliaikaisia ja intervallihyppäyksetkin kokonaisen sävelaskeleen tai jopa suurempia.

Hyvä esimerkki modulaation monipuolisesta käytöstä on ruotsalainen laulaja Carola (Häggkvist), joka on yksi Eurovision laulukilpailun historian menestyneimpiä esiintyjiä. Carola on ollut loppukilpailussa kolme kertaa: vuonna 1983 hänen esityksensä "Främling" sijoittui kolmanneksi, vuonna 1991 hän vei viisuhistorian tiukimmassa pistekilpailussa voiton kappaleella "Fångad av en stormvind" ja vuonna 2006 "Invincible" kipusi viidenneksi. Tämän lisäksi Carola on osallistunut kotimaansa viisukarsintoihin Melodifestivaleniin kahteen otteeseen, vuosina 1990 ("Mitt i ett äventyr", sijoitus toinen) ja 2008 ("One Love", Andreas Johnsonin kanssa, sijoitus viides).

Kaikki Carolan viisi viisusävelmää ovat nopeatempoisia, duurisävellajissa kulkevia kappaleita, joissa on suureellista, nostattavaa tunnelmaa. Kappaleiden tempoa pudottamalla esitykset voisi hyvin kuvitella jonkin uskonnollisen tapahtuman päätösnumeroiksi. Ajatus ei ole kaukaa haettu, sillä Carola tunnetaan hartaana kristittynä, joka on toiminut aktiivisesti Livets Ord -nimisessä herätysliikkeessä ja julkaissut useita uskonnollisia levyjä.

Jokaisessa Carolan euroviisukappaleessa on sävellajin vaihdos. Ratkaisut ovat kuitenkin vaihtelevia. Katsotaanpa tarkemmin vaikkapa viisufinaaliin yltäneitä kappaleita. Vuoden 1983 edustuskappale "Främling" tekee yhden sävelaskeleen nousun huomaamattomasti ja klassiseen viisumodulaatioon nähden hyvin varhaisessa vaiheessa ennen kuin kolmen minuutin kappaleesta on kulunut kahtakaan minuuttia. "Fångad av en stormvind" vuodelta 1991 puolestaan esittelee varsin erikoisen ratkaisun, sillä Carolan voittajakappale sisältää useita eri sävellajien vaihdoksia, jotka tulevat säännönmukaisesti vastaan siirryttäessä kappaleen eri osioista toisiin. Vaihdokset ovat tilapäisiä, eli ne eivät ole varsinaisia modulaatioita vaan sävellajipoikkeamia, sillä laulussa palataan aina alkuperäiseen sävellajiin, Bduuriin (angloamerikkalaisessa sävelnimistössä Bb-duuri). Kesken viimeisen kertosäkeen kohdassa 02:28 tapahtuu kuitenkin yhden sävelaskeleen äkkimodulaatio Des-duurista Es-duuriin. Kappaleen päättyessä ollaan alkuperäistä sävellajia peräti neljä sävelaskelta eli kvartin verran korkeammalla.

Carolan voittajaesityksessä on mukaansatempaava, yhteisöllinen tunnelma. Monien sävellajivaihdosten vuoksi laulu on kuitenkin melodisesti haastava ja ensikuulemalta hankalasti hahmottuva, ja kappaletta onkin vaikea kuvitella rippileirien yhteislauluksi tai harrastajakuorojen ohjelmistoon. Luultavasti tuomaristoja (voittaja valittiin kansallisten raatien äänillä) miellytti enemmän esityksen energisyys kuin sen musiikillinen tarttumapinta. Nokkelana yksityiskohtana laulajan hiukset heilumaan saanut tuulikone (se ei vielä tässä vaiheessa ollut viisuklisee) tehosti niin myrskytuulen vaikutelmaa kuin kappaleen tornadomaista etenemistä.

Vuoden 1991 kisajärjestelyjä Italiassa on viisuhistorioissa moitittu kehnoiksi (esim. O'Connor 2006, 124-127). Sen sai kokea myös Carola, jonka esityksen aikana saliääni meni mykäksi. Tätä ei vaivattomasta esityksestä huomaa. Kappaleen televisio-ohjauksessa sävellajien vaihdoksiin on synkronoitu kuvakulmien vaihtumisia, joita Carola seuraa tarkasti. Lopun päämodulaatiota korostetaan myös lavakoreografiassa. Tyynen väliosan jälkeen kertosäe lähtee vauhdikkaasti liikkeelle, mutta Carola ja kaksi miestanssijaa pysyvät edelleen paikoillaan, kunnes kahden tahdin jälkeen seuraa äkillinen kokosävelaskeleen hyppäys ylöspäin ja kolmikko aloittaa nopealiikkeisen tanssin. 


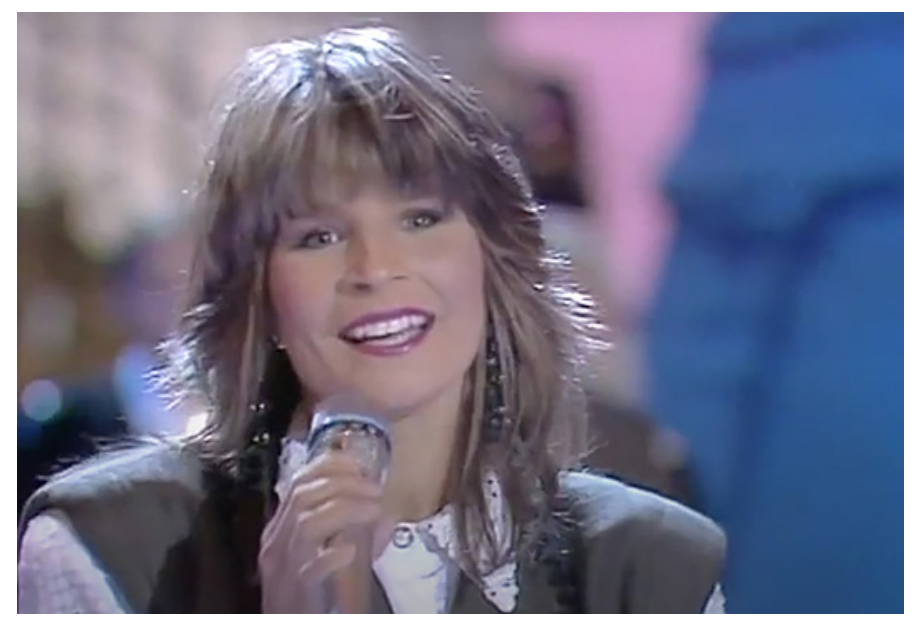

Kohta 02:15. Carola on hiljentynyt laulamaan väliosaa vuoden 1991 voittoisassa viisukappaleessa "Fångad av en stormvind". Kuva: Eurovision.tv/YouTube.

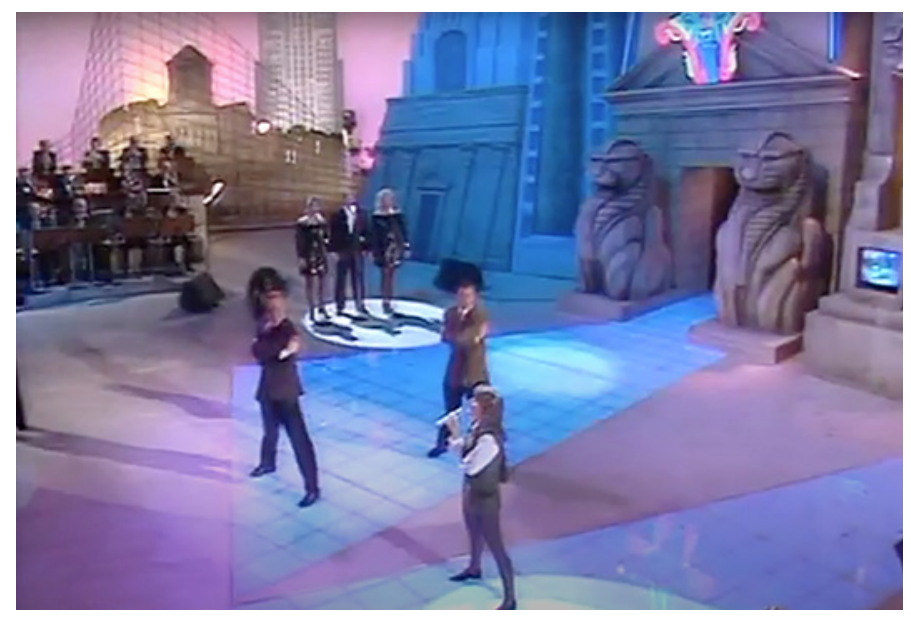

Kohta 02:27. Carola ja mieslaulajat ovat jähmettyneet paikoilleen viimeisen kertosäkeistön rullatessa jo täyttä vauhtia eteenpäin. Sekuntia myöhemmin sävellaji nousee ja kolmikko lähtee liikkeeseen. Kuva: Eurovision.tv/ YouTube.

Carolan viisukappale "Invincible" vuodelta 2006 puolestaan tarjoaa vain yhden sävellajin vaihdoksen ja melko tavanomaisessa vaiheessa, kohdassa 02:14, kun takana on kaksi laulusäkeistöä ja käsittelyssä on lyhyt väliosa eli "bridge", joka johdattelee sävellyksen kohti viimeistä, pidennettyä kertosäkeistöä. Esityksessä on klassisen viisumodulaation makua. Musiikkitaustassa on muutaman sekunnin tauko, mutta Carola jatkaa silmät suljettuina pitkää laulusäveltä alaleuka kevyesti väpättäen, kohottaa vapaata kättään, ja samalla hetkellä kun kasvoihin kohdistunut tv-kuva vaihtuu yläilmoihin etääntyvään lavaotokseen, laulajan ääni liukuu puoli sävelaskelta ylöspäin. Säestys tulee mukaan. Valot välähtelevät. Liput, lakanat ja kampaukset liehuvat. Kaikki tapahtuu hyvin nopeasti, vain muutamassa sekunnissa.

\section{Modulaatio musiikillis-visuaalisena konventiona}

Eurovision laulukilpailuja tutkinut Ivan Raykoff (2020, 59-65) väittää, että modulaatio on ollut käytössä pitkin viisuhistoriaa jo heti vuoden 1956 ensimmäisestä kilpailusta lähtien. Edustuskappaleissa on esitetty useita erilaisia modulaatioratkaisuja, ja voittoihinkin on ylletty moneen otteeseen. Yhtenä käännekohtana voidaan pitää vuotta 1967, jolloin Iso-Britannian Sandie Shaw voitti kilpailun modulaatiota hyödyntäneellä kappaleellaan "Puppet on a String". Tämän jälkeen sävellajin vaihdos juhli voittoa vielä neljänä vuonna peräkkäin. Kaikkinensa vuosien 1967 ja 2010 välillä 22 voittajalaulua 47:stä hyödynsi modulaatiota. Modulaatiokappaleet olivat tyypillisesti duurisävellyksiä. (Raykoff 2020, 59-65.) 
Raykoff keskittää modulaatiota koskevassa selvityksessään huomion erilaisiin sävellysteknisiin ratkaisuihin. Hän ei erityisemmin analysoi sävellajin vaihdokseen liittyviä audiovisuaalisen esittämisen tapoja ja niiden muutoksia tai tehokeinon suosion syitä. Olisikin kiinnostavaa pohtia tarkemmin, millä tavalla viisumodulaatio kytkeytyy musiikinteorian lisäksi estraditaiteen ja televisioviihteen perinteeseen. Voidaan nimittäin hyvällä syyllä väittää, että tämä kytkentä on ollut merkittävä ja että siihen on samalla sisältynyt tiettyä intensiteetin muutosta. Vaikka modulaatiota käytettiin Eurovision laulukilpailussa monipuolisesti alusta lähtien, sen esityksellinen luonne oli vuosikymmenien ajan kohtalaisen hillitty. Vielä niinkin myöhään kuin vuonna 1988 Céline Dionin voittajakappale "Ne partez sans moi" esitteli yhden sävelaskeleen nousun ilman suurempia alleviivauksia hieman samaan tapaan kuin Carola oli tehnyt viisi vuotta aiemmin.

Joidenkin tarkentamattomien lausuntojen mukaan (esim. Jameson 2013; Griffiths 2015 , 28) modulaation käyttöä on viisuhistorian aikana suosittu etenkin Ruotsissa. Ruotsalaisten esityksistä kieltämättä löytyy monipuolisia sävellajin vaihdoksia kuten myös niiden esittämiseen liittyviä muutoksia. Carolan viisuesitykset vuosilta 1983, 1991 ja 2006 ovat hyvä esimerkki modulaation dramaattisuuden ja intensiteetin kasvusta: alkuun näppärä tehokeino formuloidaan lopulta audiovisuaaliseksi suurnäytökseksi. Toista ruotsalaista esimerkkiä hyödyntäen voidaan väittää, että modulaatiomuodin käännekohta tapahtui vuosituhannen vaihteessa. Vuoden 1999 voittaja Charlotte Nilsson käytti painokasta, yhden sävelaskeleen vaihdosta laulussaan "Take Me to Your Heaven". Nilssonin jälkeen modulaatio osoittautui voittoisaksi myös kahtena seuraavana vuonna, ja erityisesti tanskalaisen Olsen Brothersin voittokappaleessa "Fly on the Wings of Love" vuonna 2000 menetelmään sisällytettiin spektaakkelimaista näyttävyyttä.

Viisikymppisen miesduon vanhahtava mutta rytmikäs keskitempoballadi ei ennakkokaavailuissa lukeutunut suosikkeihin, mutta se voitti kilpailun selkeästi. Yliohjautuvaan autotune-efektiin perustuva robottimainen lauluääni-efekti on usein mainittu ratkaisevaksi tekijäksi, mutta yhtä lailla huomio kannattaa kiinnittää kohdassa 2:30 toteutettuun modulaatioon. Juuri ennen siirtymää on hiljennytty

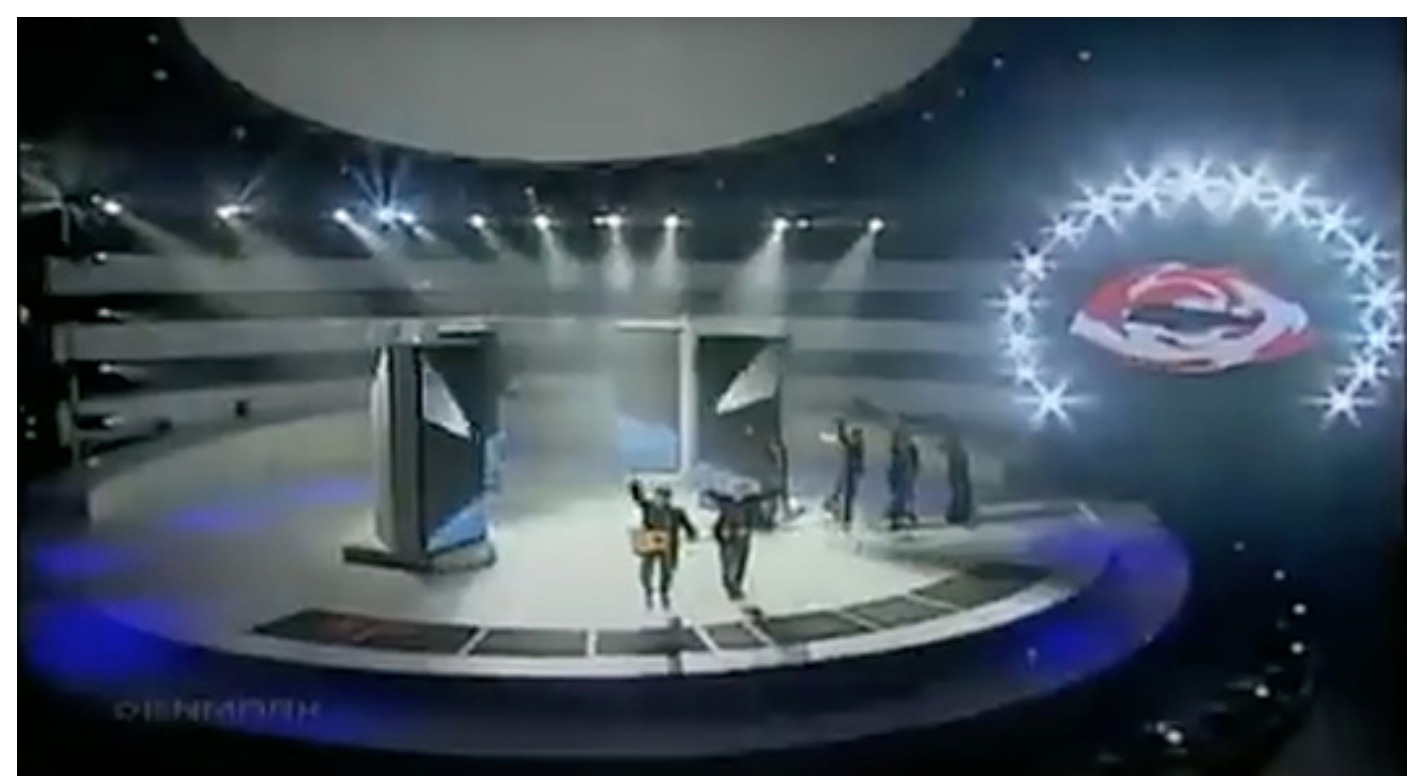

Televisiokamera on perääntynyt kymmenien metrien päähän esiintymislavasta vangitakseen mahdollisimman laajasti Olsenin veljesten voittokappaleen "lasermaisen" äkkimodulaation. Kuva: Eurovision.tv/YouTube. 
kuulemaan rauhallisesti esitettyä kertosäkeistöä, jonka aikana kamera etääntyy rauhallisesti yläviistoon kohti kattoa. Kertosäkeistön lopussa tulee puolen tahdin mittainen tauko, joka päättyy perkussiiviseen valojen sävähdykseen: kappale "hyppää" kokosävelaskeleen ylöspäin. Täysi säestys käynnistyy välittömästi, ja kuva tarkentuu veljeksiin, jotka johdattavat kappaleen kertosäkeistöä toistamalla loppuun asti. Ruotsalaisilla oli näppinsä pelissä tässäkin modulaatiossa, sillä kilpailu järjestettiin Tukholmassa ja tv-ohjauksesta ja samalla Olsen Brothersin näytteillepanosta vastasi Ruotsin yleisradioyhtiö SVT.

Modulaatiotrendi saavutti huippunsa pian tämän jälkeen. Matt Friedrichs (2013) väittää blogikirjoituksessaan, että vuosina 2000-2012 viisufinaalin 460 esityksestä 201 eli 43,7 prosenttia sisälsi sävellajin vaihdoksen. Huippuvuonna 2003 lähes kaksi kolmasosaa kappaleista tukeutui modulaatioon. Vuoden 2006 finaalissa koettiin sitten Carolan ja Anna Vissin hurmiolliset äkkisiirtymät. Ajanjakson loppua kohden trendi hiipui, ja vuonna 2012 modulaatio esiintyi Friedrichsin mukaan vain joka kuudennessa kappaleessa.

Toistaiseksi viimeisin modulaatiota hyödyntänyt euroviisuvoittaja on vuodelta 2007, jolloin Serbian Marija Šerifović käytti esityksessään "Molitva" kokosävelaskeleen nousua kahteen otteeseen. Ylättävänä ratkaisuna ensimmäinen vaihdos toteutettiin pelkästään taustasäestyksen voimin laulajan itsensä kävellessä taka-alalle. Joissakin tulkinnoissa modulaation hyödyntäjäksi on laskettu myös vuoden 2014 voittajasävelmä, itävaltalaisen Conchita Wurstin "Rise Like a Phoenix". Se kyllä leikittelee vaihdoksen mahdollisuudella, mutta ei kuitenkaan hylkää alkuperäistä sävellajia.

\section{Puhelin sävellajin vaihtajana}

Modulaation valtavuodet osuvat Eurovision laulukilpailun historian kannalta mielenkiintoiseen ajanjaksoon. Itäeurooppalaiset rynnivät laajalla rintamalla kilpailuun ja tarjosivat samalla uudenlaista musiikkiestetiikkaa, joka hyvien tulosten perusteella tuntui kiinnostavan myös äänestäjiä. Vuoden 2007 kilpailussa Helsingissä 16 parhaan joukossa oli Turkin ja Kreikan seurana 14 entisen Neuvostoliiton valtapiiriin kuulunutta maata (Mäkelä 2014). Voisi olla mielenkiintoista pohtia tarkemmin, oliko modulaatiolla jokin rooli tässä kehityksessä.

Yhtä lailla tarkemman analyysin ansaitsisi se, millainen vaikutus modulaation nousuun ja jalostumiseen Eurovision laulukilpailussa oli kolmella suurella muutoksella, jotka osuivat vuosituhannen vaihteeseen: elävä orkesteri katosi, esityskieli vapautui ja puhelinäänestys otti vallan.

Vuoteen 1998 asti kilpailussa oli ollut mukana kapellimestarin johtama laaja orkesteri pääosin akustisine soittimineen. Kun taustaäänitykset korvasivat elävän orkesterin (taustanauhoja oli kyllä enemmän tai vähemmän käytetty jo vuodesta 1973), moderni popilmaisu sai enemmän tilaa samoin kuin lavashow, jota kehittynyt tekniikka monikamera-ajoineen ja digitaalisine taustanäyttöineen tehosti. Esityskielen vapautuminen puolestaan merkitsi sitä, että esiintyjät saivat laulaa kappaleensa muullakin kuin oman maansa kielellä. Käytännössä lähes kaikki esittivät kappaleensa englanniksi, ja solistin viesti, joka usein huipentui modulaatiovaiheessa, tuli paremmin ymmärrettäväksi yleisön parissa.

Vuonna 1999 puolestaan otettiin tuomariston päätöksien tilalle puhelinäänestys, jota oli jo parin vuoden ajan ajettu sisään. Kyseessä oli viisuhistorian suurin sääntömuutos sitten tapahtuman perustamisen, ja voidaan hyvällä syyllä väittää, että äänivallan siirryttyä suurelle yleisölle spektaakkelimaiset esillepanot ja sävellys- ja sovitustekniset dramatisoinnit nousivat menestyskappaleiden tärkeimmiksi resepteiksi. Modulaatiolle osuikin heti tähän saumaan kolmen vuoden voittoputki. 
Massaäänestyksen mahdolliset vinoumat ja alueelliset blokkiutumiset herättivät vuosien ajan kovaa keskustelua. Puhelinäänestyksen asemaa heikennettiinkin vuonna 2009 sääntömuutoksella ja samalla siirryttiin sekatekniikkaan, jossa pisteet määriteltiin puoliksi asiantuntijaraatien avulla. Itä-Euroopan voittoisa vuosikymmen jäi taakse - ja myös jotain muuta. Friedrichs (2013) pohtii, että kenties juuri tämän sääntömuutoksen vuoksi lauluntekijät alkoivat kaihtaa sävellajin vaihdosta edustuskappaleissaan. Suuri yleisö saattoi rakastaa modulaatiota ja niiden esillepanoa, mutta tuomaristot inhosivat niitä. Vaikka tälle hypoteesille on vaikea löytää todisteita, viisuhistorian aikana on tavan takaa väitetty, että asiantuntijaraadit eivät lämpene liian populaareiksi ja kaupallisiksi mielletyille esityksille.

Modulaatiohuuma alkoi joka tapauksessa laantua. Huomiota herättävän efektin yleistyttyä sen yllätysmahdollisuudet hupenivat 2010-luvulla, ja vaikka tehokeino ei ole kokonaan kadonnut, sävellajin vaihdos tuntuu viisuja koskevissa keskusteluissa ja puheenvuoroissa herättävän enemmän naureskelua kuin ihailua. Uusia ilmaisuja ei ole juurikaan etsitty, vaikka mahdollisuuksia menetelmän hyödyntämiselle voisi edelleen löytyä: Mitä jos vaihdos olisi kaksi sävelaskelta? Tai voisiko sävellajia kenties pudottaa? Toisaalta sävellys- ja soinnutustrendi ei ole enää vähään aikaan ollut muutenkaan suosiollinen modulaation kaltaisille keinoille. Modulaatiot ovat olleet ominaisia duurikappaleille, mutta viime vuosina viisuja ovat hallinneet mollisävellykset.

Anna Aljanaki (2019) puolestaan on osoittanut "täydellistä Eurovisio-laulua" koskevassa data-analyysissaan, että kilpailukappaleissa uniikkien sointujen määrä väheni pitkin 2010-lukua. Käytännössä säveltäjät saattavat nykyisin viisukappaleita laatiessaan tyytyä kolmeen neljään sointuun, ja usein sointukuvio jopa pysyy samana siirryttäessä osiosta toiseen. Korvakuulolta sävellysten sointupohjan kapeneminen on ollut havaittavissa valtavirran popmusiikissa laajemminkin.

\section{Lopuksi}

Olen tässä kirjoituksessa luonut katsauksen modulaation tapaisen menestysreseptin käyttöön Eurovision laulukilpailun historiassa. Sävellajin vaihtumiselle ei alkuun haettu "ulkomusiikillisia" painotuksia, mutta tehokeinon osoittauduttua toimivaksi näitä ryhdyttiin kehittelemään. Koska sävellaji säännönmukaisesti nousi ylöspäin ja ikään kuin toi kappaleeseen ylimääräisen vaihteen, koreografisia ja visuaalisia kerrontatapoja ei lopulta ollut kovinkaan vaikea luoda. Merkittävänä rajapyykkinä voidaan pitää vuotta 2000 ja tanskalaisen Olsen Brothersin voittosävelmää, jossa modulaation visualisointi on suunniteltu tarkkaan.

Monia musiikillisia tai pikemminkin sävellysteknisiä ratkaisuja, kuten esimerkiksi sointujen kvinttikiertoa, on hankala esittää visuaalisin keinoin. Modulaation kohdalla tätä ongelmaa ei ole ollut. Viisukappaleissa sävellajin vaihdos tapahtuu yleensä nopeasti, mutta sen merkitys Eurovision laulukilpailun audiovisuaaliselle estetiikalle on ollut hämmästyttävän suuri. Itse asiassa aiheesta riittäisi edellä esitettyjen pohdintojen lisäksi runsaasti tutkittavaa varsinkin media- ja kulttuurintutkimuksen alalla. Pitääkö esimerkiksi paikkansa, että modulaatio on ollut leimallisesti naislaulajien ja varsinkin "euroviisudiivojen" tehokeino? Tai millaiset kytkennät sen esittämisellä ja siihen liittyvillä televisiointiratkaisuilla on vaikkapa musiikkivideoperinteeseen, Disney-elokuviin ja afrikkalaisamerikkalaisen musiikin kuten gospelin audiovisuaalisiin esityksiin?

Ja nyt seuraa äkkihyppäys. Katsaukseni lopuksi on hyvät perusteet "moduloitua" takaisin ruotsalaisiin ja vuoteen 2016. Petra Meden ja Måns Zelmerlöwin ohjelmanumeroa seuratessa mieleen nousee, että myös Eurovision laulukilpailun väliaika- 
esitykset ovat kiinnostava tutkimuskohde. Mitä ne kertovat kansallisuudesta? Tai millaista näkemystä väliaikanumerot ovat esittäneet Eurovision laulukilpailun omasta historiasta?

Ruotsalaisjuontajien resepti täydellisen viisukappaleen luomisesta edustaa parodista näkökulmaa mutta etäännytetysti, sillä irvailun kohteeksi joutuneet esimerkit ovat ainakin menestysnäkökulmasta katsottuna selvästi vanhentuneet. Ajallisesti esityksen viittaukset tarkentuvat vuosikymmenen verran taaksepäin osuen ItäEuroopan viisumenestyksen ja -estetiikan nousukauteen. Joiltain osin tarkentuma ulottuu kauemmaksikin - ja samalla maantieteellisesti ja kulttuurisesti lähelle, sillä ei ole liioittelua väittää, että Carolan johdolla nimenomaan ruotsalaiset esiintyjät olivat ensimmäisten joukossa popularisoimassa näyttävää modulaatiota osaksi Eurovision laulukilpailun musiikillis-visuaalista esillepanoa.

\section{Lähteet}

Aljanaki, Anna (2019) On a Quest for a Perfect Eurovision Song with Data Science. Mooncascade. Saatavilla: https://blog.mooncascade.com/on-a-quest-for-a-perfect-eurovision-song-with-data-science/ (linkki tarkistettu 18.2.2021).

DS Fantasy (2021) Best European Key Change. DS-Fantasy Eurovision. Saatavilla: https://dsfantasyesc. fandom.com/wiki/Best_Eurovision_Key_Change (linkki tarkistettu 18.2.2021).

Friedrichs, Matt (2013) Key Changes in ESC - A Eurovision Strategy? Escunited. Saatavilla: https://www. escunited.com/key-changes-in-esc-a-eurovision-strategy/ (linkki tarkistettu 18.2.2021).

Griffiths, Dai (2015) Elevating Form and Elevating Modulation. Popular Music 34/1, 22-44.

Jameson (2013) Top 10: Best key-Changes in ESC History. ESC Views. 21.9.2013. Saatavilla: https:// escviews.wordpress.com/2013/09/21/top-10-best-key-changes-in-esc-history/ (linkki tarkistettu 18.2.2021).

Mäkelä, Janne (2014) Pophistoria. Kuinka musiikki muutti maailman. Helsinki: Klaava Media \& Musiikkiarkisto. Saatavilla: https://musiikkiarkisto.fi/oa/

O'Connor, John Kennedy (2016) Euroviisut, virallinen historia. Alk. The Eurovision Song Contest - The Official History. Suom. Marja Lyytinen. Helsinki: Ajatus Kirjat.

Pajala, Mari (2006) Erot järjestykseen! Eurovision laulukilpailu, kansallisuus ja televisiohistoria. Nykykulttuurin tutkimuskeskuksen julkaisuja 88. Jyväskylä: Jyväskylän yliopisto.

Raykoff, Ivan (2020) Another Song for Europe. Music, Taste and Values in the Eurovision Song Contest. Lontoo: Routledge.

Scott, Derek B. (2010) Musical Style and Social Meaning. Lontoo: Routledge. 